No $2011-09$

April

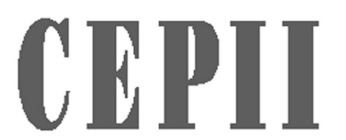

CENTRE

D'ÉTUDES PROSPECTIVES

ET D'INFORMATIONS

INTERNATIONALES

Carbon Price Drivers: Phase I versus Phase II

Equilibrium?

Anna Creti, Pierre-André Jouvet, Valérie Mignon 


\section{TABLE OF CONTENTS}

Non-technical summary. . . . . . . . . . . . . . . . . . . . . . . . . . . 3

Abstract . . . . . . . . . . . . . . . . . . . . . . . . . . 4

Résumé non technique . . . . . . . . . . . . . . . . . . . . . 5

Résumé court . . . . . . . . . . . . . . . . . . . . . . . . 6

1. Introduction . . . . . . . . . . . . . . . . . . . . . . . . . . . . . . 7

2. Permit price: some theory and stylized facts . . . . . . . . . . . . . . . . . 9

3. Data . . . . . . . . . . . . . . . . . . . . . . . . . . 12

4. Cointegration and causality results . . . . . . . . . . . . . . . . . . . . . 14

5. Equilibrium carbon price . . . . . . . . . . . . . . . . . . . . . . . . . 17

6. Conclusion . . . . . . . . . . . . . . . . . . . . . . . . . . 22

List of working papers released by CEPII . . . . . . . . . . . . . . . . . 30 


\section{Carbon Price Drivers: Phase I versus Phase II Equilibrium?}

\section{NON-TECHNICAL SUMMARY}

The EU Directive 2003/87/EC has established a scheme, the so-called European Union Emission Trading Scheme (henceforth EU ETS) for trading greenhouse gas emission allowances within the Community. The Pilot Phase of the system covered the period 2005-2007. Since January 2008, the scheme has entered Phase II, which will end in 2012 with the achievement of the Kyoto target.

Much has been written so far on the EU-ETS in Phase I, despite the first period was meant to be a learning process. Together with the environmental effectiveness and the cost-efficiency of the instrument, academics have investigated carbon price patterns in 2005-2007 and discussed either their determinants or the most suitable stochastic behaviours to forecast such patterns.

A few papers have investigated Phase II, which differs from Phase I of the EU ETS in terms of market expertise, characteristics (liquidity and depth), and regulation. Given these differences, we would notably like to test whether the results for Phase I can be extended to Phase II. More specifically, our aim in this paper is to shed some light on the determinants of carbon futures price in Phase II by testing whether the carbon price drivers identified so far by the economic literature-such as energy prices and indicators of economic activity—still hold for the EU ETS in Phase II and evolve toward a stable long-run relationship.

From a methodological viewpoint, we consider daily futures contracts and rely on cointegration techniques to identify the carbon price determinants both on the whole period (June 24, 2005 to December 20, 2010), and on the two subperiods corresponding to Phases I and II of the EU ETS. Our results show that while a cointegrating relationship exists between the carbon price and its fundamentals during Phase II of the EU ETS, such an equilibrium relationship can be obtained for Phase I only if the 2006 structural break occurred on the carbon market is accounted for. On the whole, our findings highlight that equilibrium relationships exist for both phases of the EU ETS, with an increasing role of fundamentals in Phase II. Calculations of equilibrium prices show that while the observed carbon price was close to its equilibrium value and then overvalued at the beginning of Phase II, it has been undervalued since the end of 2009. 


\begin{abstract}
The aim of this paper is to investigate the determinants of the carbon price during the two phases of the European Union Emission Trading Scheme (EU ETS). More specifically, relying on daily EU allowance futures contracts, we test whether the carbon price drivers identified for Phase I still hold for Phase II and evolve toward a long-run relationship. Using cointegration techniques and accounting for the 2006 structural break on the carbon market, we show that while a cointegrating relationship exists for both phases of the EU ETS, the nature of this equilibrium relationship is different across the two subperiods, with an increasing role of fundamentals in Phase II. Deriving equilibrium values, we show that the carbon price tends to be undervalued since the end of 2009.
\end{abstract}

JEL Classification: Q4, C22.

Keywords: $\quad$ EU ETS, carbon price, energy prices, cointegration. 


\section{LES DÉTERMINANTS DES PRIX DU CARBONE : UNE COMPARAISON ENTRE LES PHASES}

\section{RÉSUME NON TECHNIQUE}

La directive 2003/87/EC de l'Union Européenne a établi un système pour les échanges de permis d'émission des gaz à effet de serre au sein de la Communauté, le "système d'échange des quotas européens" (European Union Emissions Trading Scheme, EU ETS). La phase pilote du système (phase I) couvre la période 2005-2007. Depuis janvier 2008, le système est entré en phase II, qui doit s'achever en 2012 avec le respect des cibles fixées par le protocole de Kyoto.

Alors même que la phase I était perçue comme une phase temporaire d'apprentissage, celle-ci a fait l'objet d'un grand nombre de travaux dans la littérature. Outre l'intérêt porté à l'efficacité environnementale et à l'analyse coûts / bénéfices d'un tel système, certains auteurs se sont centrés sur l'étude de l'évolution des prix du carbone sur la période 2005-2007. Plusieurs travaux ont porté sur les déterminants des prix du carbone, d'autres ont recherché la modélisation la plus adéquate pour prévoir leur évolution.

A contrario, très peu de travaux ont été menés sur la phase II. Les phases I et II de l'EU ETS diffèrent en termes d'expertise, de caractéristiques (liquidité et profondeur financière) et de régulation des marchés. Etant donné ces différences, notre objectif est de tester si les résultats et mécanismes mis en évidence pour la phase I sont applicables pour la phase II. Plus spécifiquement, nous testons si les déterminants des prix du carbone identifiés pour la phase I, comme les prix de l'énergie et divers indicateurs de l'activité économique, sont toujours valables pour l'EU ETS en 2008 et évoluent suivant une relation stable de long terme.

Au niveau méthodologique, nous considérons les contrats sur futures à fréquence quotidienne et recourons aux techniques de cointégration. Nous montrons qu'alors qu'une relation d'équilibre existe entre les prix du carbone et les fondamentaux durant la phase II, une telle relation de long terme ne peut être obtenue pour la phase I que si la rupture intervenue en 2006 sur le marché des permis est prise en compte. Globalement, nos résultats montrent qu'une relation d'équilibre existe sur les deux phases de l'EU ETS, avec un rôle croissant des fondamentaux durant la deuxième phase. Le calcul des prix d'équilibre montre en outre que les prix du carbone sont sous évalués depuis fin 2009. 


\section{RÉSUMÉ COURT}

L'objectif de cet article est d'étudier les déterminants des prix du carbone durant les deux phases du système d'échange des quotas européens concernant les permis d'émission des gaz à effet de serre (EU ETS). Plus spécifiquement, en considérant les contrats sur futures à fréquence quotidienne, nous testons si les déterminants des prix du carbone identifiés pour la phase I sont toujours valables pour la phase II et évoluent suivant une relation stable de long terme. En recourant aux techniques de cointégration et en tenant compte de la rupture intervenue en 2006 sur le marché des permis, nous montrons qu'une relation de cointégration existe pour les deux phases de l'EU ETS, mais que la nature de cette relation d'équilibre est différente entre les deux sous périodes, avec un rôle croissant des fondamentaux durant la phase II. Le calcul des valeurs d'équilibre montre en outre que les prix du carbone tendent à être sous évalués depuis fin 2009.

Classification JEL: Q4, C22.

Mots clés : $\quad$ EU ETS, prix du carbone, prix de l'énergie, cointégration. 


\title{
Carbon Price Drivers: Phase I versus Phase II Equilibrium? ${ }^{1}$
}

\author{
Anna Creti*, Pierre-André Jouvet ${ }^{\dagger}$, and Valérie Mignon ${ }^{\ddagger}$
}

\section{INTRODUCTION}

The European Union Emission Trading Scheme (henceforth EU ETS) is the first large scale $\mathrm{CO}_{2}$ emission trading system in the world. Created in 2003 by the EU Directive 2003/87/EC, EU ETS entered into force in 2005, covering more than 10,000 industrial installations in 25 countries. The European market was organized in three phases: Phase I in 2005-2007, Phase II in 2008-2012, Phase III would be the arrangement starting in 2013 until 2020. Past 2020, the EU ETS is set to expire if no further international climate agreement is reached. The first period is considered the 'trial phase' in which administrative and regulatory bodies were put on-line. Moreover, credits from Phase I couldn't be carried over, or 'banked', to subsequent years. Phase II represents the fundamental regulatory tool allowing Member States to reach their Kyoto target. In fact, in the current phase, European Union Allowances (EUAs) are conversions of AAUs (Assigned Amount Units), the permits allocated to Annex B Parties of the Kyoto Protocol. In the same way, countries can use emission credits from project mechanisms in the emission trading system associated to the Kyoto Protocol ${ }^{2}$ to meet part of their emission reduction targets with credits (Certified Emissions Reductions or Emissions Reduction Units) starting from 2008. Finally, Phase III is set to help meet the European target of $20 \%$ greenhouse gas emission reduction in 2020 compared to 1990, in line with the objectives of the Climate Energy Package approved in December 2008.

In 2005, major emitters were allocated an initial amount (larger than 2 billion) of permits for free. They were then free to trade these permits in the market, knowing that they would have to be able to hold at verification times an amount of permits corresponding to the amount of emissions of the previous year. Lacking this compliance, companies would have to pay sanctions (40

\footnotetext{
${ }^{1}$ We thank Agnès Bénassy-Quéré for helpful comments and suggestions, and Boris Solier for valuable discussions. *EconomiX-CNRS, University of Paris Ouest, and Ecole Polytechnique, France. E-mail: acretibettoni@u-paris10.fr

${ }^{\dagger}$ EconomiX-CNRS, University of Paris Ouest, and Climate Economics Chair, Paris, France. E-mail: pjouvet@u-paris10.fr

${ }^{\ddagger}$ Corresponding author. EconomiX-CNRS, University of Paris Ouest and CEPII, Paris, France. Address: University of Paris Ouest, 200 avenue de la République, 92001 Nanterre Cedex, France. Phone: +33 (0)1 40975860. Fax: +33 (0)1 409777 84. E-mail: valerie.mignon@u-paris10.fr

${ }^{2}$ Industrial installations covered by the EU ETS are allowed to do that since the vote of the "Linking Directive" in 2004 .
} 
$€ /$ ton plus the purchase of the missing permits in Phase I). ${ }^{3}$ An identical new supply was given every year to the same sources. The goal of the EU ETS is to force major polluters (especially in the energy, metals and minerals sectors) to phase down the emissions of $\mathrm{CO}_{2}$ gradually over time, leaving to the private sector the choice of the best way to achieve the target. Emitters who can efficiently decrease emissions can sell some of their permits on the market; emitters who cannot efficiently decrease emissions have then to buy extra permits. The market involves both spot and futures contracts. ${ }^{4}$

Much has been written so far on the EU ETS in Phase I, despite this first period was meant to be a learning process. Together with the environmental effectiveness and the cost-efficiency of the instrument, academics have investigated carbon price patterns in 2005-2007 and discussed either their determinants (Mansanet-Bataller et al., 2007; Alberola et al., 2008a, 2009) or the most suitable stochastic behaviors to forecast such patterns (Daskalakis et al., 2007; Paolella et al., 2007; Seifert et al., 2008; Benz et al., 2009).

A few papers have investigated Phase II, which differs from Phase I of the EU ETS in terms of market expertise, characteristics (liquidity and depth), and regulation. Given these differences, we would notably like to test whether the results for Phase I can be extended to Phase II. More specifically, our aim in this paper is to shed some light on the determinants of carbon futures price in Phase II by testing whether the carbon price drivers identified so far by the economic literature - such as energy prices and indicators of economic activity-still hold for the EU ETS in Phase II and evolve toward a stable long-run relationship.

From a methodological viewpoint, we consider daily futures contracts which are more traded and less sensitive to the important structural changes that have occurred on the spot market (Mansanet-Bataller and Pardo, 2008). Similarly to Bredin and Muckley (2010), we rely on cointegration techniques to identify the carbon price determinants both on the whole period (June 24, 2005 to December 20, 2010), and on the two subperiods corresponding to Phases I and II of the EU ETS. Our paper extends Bredin and Muckley (2010) along two directions. First, we take into account the "compliance break" in 2006, which had a strong impact on the EU ETS market during Phase I, when the discovery of counterfactual emissions with a corresponding overallocation has led a four days lasting collapse of EUA prices. Second, we derive the equilibrium prices implied by the cointegrating relationship both in Phase I and in Phase II, and unveil the main reasons for the discrepancies between the predicted and observed prices.

Our results show that while a cointegrating relationship exists between the carbon price and its fundamentals during Phase II of the EU ETS, such an equilibrium relationship can be obtained

\footnotetext{
${ }^{3} 100 € /$ ton plus the purchase of the missing permits in Phase II.

${ }^{4}$ For an in-depth analysis of the EU ETS first phase, see Ellerman, Convery and de Perthuis (2010).
} 
for Phase I only if the 2006 structural break occurred on the carbon market is accounted for. On the whole, our findings highlight that equilibrium relationships exist for both phases of the EU ETS, with an increasing role of fundamentals in Phase II. Calculations of equilibrium prices show that while the observed carbon price was close to its equilibrium value and then overvalued at the beginning of Phase II, it has been undervalued since the end of 2009 .

The rest of the paper is organized as follows. Section 2 highlights some theoretical points and stylized facts regarding the evolution of the EU ETS since the beginning of the first phase. Section 3 presents the data, and Section 4 displays the results of cointegration and causality tests. In Section 5, we proceed to a comparison analysis between the dynamics of the carbon price during Phases I and II, and provide results regarding the equilibrium value of this price. Section 6 concludes the paper.

\section{PERMIT PRICE: SOME THEORY AND STYLIZED FACTS}

The economic explanation of the market for permits (authorizations to emit a specific amount, usually one ton, of a specific pollutant) as an economic tool to achieve environmental regulation dates back to Crocker (1966), Dales (1968), and Montgomery (1972). The basic rationale behind market-based instruments is that permits are either auctioned off or distributed among emitters on the basis of some criterion such as historical use. As long as marginal abatement costs to reduce pollution differ across regulated firms, incentives for trade exist. High marginal abatement cost firms buy permits from low marginal cost firms until the market clears and the demand for permits equals the fixed supply, that is the permits initially allocated by the regulator.

Several theoretical propositions about emission trading have been demonstrated. In particular, a cap-and-trade system achieves the set reduction in aggregate emissions at a minimum total cost. This means that a central planner that jointly minimizes the costs of all polluters cannot reduce aggregate costs of all polluters compared to the scenario of emissions trading. A by-product of solving the firms' pollution cost minimization problem in the cap-and-trade setting is that a convenient interpretation of the permit price is obtained. In a (deterministic) equilibrium model, the permit price is equal to the marginal abatement cost which does neither explicitly depend on the regulations of an emissions trading scheme such as the penalty for non compliance and the number of allocated permits nor on the expected future emissions of the regulated companies. Along this line, Tietenberg (1985), Cronshaw and Kruse (1993), and Rubin (1996) show that:

$$
\mathbf{P}_{t}=\mathbf{M C}_{t} \forall \mathbf{t} \in[0, T]
$$

where $P_{t}$ is the permit price at time $t, M C_{t}$ is the marginal cost to reduce one ton of pollutant at time $t$, and $T$ is the end of the regulated period. 
The simple relationship in Equation (1) represents the theoretical counterpart for the empirical analysis on carbon price drivers, whose main challenge is to find convenient proxies for firms' abatement costs. These latter depend on the various emission reducing alternative available to regulated firms, as well as on indicators of economic activity which stands for the link between production and emissions.

In the empirical literature on the EU ETS, given that the electricity sector is responsible for almost $39 \%$ of the European $\mathrm{CO}_{2}$ emissions and thus represents the most important sector covered by the current European regulation (Christiansen et al., 2005), much effort has been devoted to measure energy related abatement costs. The impact of energy prices in a time series context has been analyzed by Mansanet-Bataller et al. (2007) and Alberola et al. (2008a,b, 2009) among others. ${ }^{5}$ However, institutional determinants have shown equal importance. Indeed, Phase I price patterns have been strongly impacted by institutional factors, in particular the so called "compliance break". In fact, the disclosure of 2005 verified emissions in April 2006 proved the National Allocation Plans for Phase I were too generous provoking the EUA spot price to fall from 29.5 euros to less than 12 in a few days. In Alberola et al. (2008a), subperiods investigations make clear that policy proxies are the main driver of carbon prices before the compliance break (June 2005-April 2006), while energy fundamentals govern carbon price trajectories henceforth (May 2006-April 2007). Those findings are further tested by Alberola et al. (2009) who look at the effect of policy uncertainty on carbon prices by introducing a proxy to capture the impact of information revelation. ${ }^{6}$ Information disclosure is statistically significant for 2005, not for 2006. Therefore, the allowance squeeze probability did constitute a carbon price driver for the EU ETS spot market in 2005 but not in 2006. Awaiting short positions of the installations covered by the EU ETS, both compliant agents and speculators bought EUAs on March-April 2006. On the contrary, no transactions occurred in March-April 2007, since operators expected the emission cap to be non-binding. Further analysis by Hintermann (2010), based on a simple structural model of allowance price, suggests that while prices were not initially driven by marginal abatement costs, this inefficiency was corrected after the accounting of the compliance break.

All the above mentioned analyses consider spot or over-the-counter prices. The futures price, instead, has shown different patterns. First, it continued to display a stable path after the compliance break, thus showing the disconnection between spot and futures prices. Second, since October 2006, while the EUA spot price started converging towards 0 due to the non bankability of Phase I prices, futures with expiration on the second Phase settled above 20 euros. Milunovich and Joyeux (2007) show that, while futures with maturities 2006 and 2007 exhibit a

\footnotetext{
${ }^{5}$ For an extensive review on carbon price drivers, see Chapter 5 in Ellerman, Convery and de Perthuis (2010).

${ }^{6}$ This proxy has been constructed by multiplying the allowance squeeze probability (computed at time $t$ the number of days remaining before the yearly compliance event, that is April 30th) by a dummy that takes the value of one fifteen days prior to the official yearly verified emissions announcement, and is zero otherwise.
} 
stable long-run cointegrating relationship with Phase I spot price, the 2008 futures do not form such relationship but they rather act as a vehicle of price discovery for Phase II spot price due to the non-bankability of Phase I permits. These findings question the existence of an equilibrium in futures price contracts in the EU ETS. Bredin and Muckley (2010) address this issue. They look for an equilibrium relationship between carbon futures prices and several fundamentals, such as oil price, energy spreads for electricity production, the Euro Stoxx 50 together with the Eurostat index of industrial production (interpolated to obtain daily data) and a temperature index (set as deviations from a weighted European monthly average). The cointegration analysis, which takes into account volatility and uncertainty effects, reveals that an equilibrium relationship between carbon futures prices and energy prices only holds in Phase II.

However, previous studies using cointegration have shown some (although partial) effects of equilibrium relationship during Phase I. In particular, Bunn and Fezzi (2008) examine the interactions between emission markets and a range of UK energy markets within a VAR cointegrated approach. The authors find that the gas price influences the EUA price, and that both gas and EUA prices help determine the electricity price. Rickels et al. (2007) check for cointegration between allowance and fuel prices in the very first period of the EU ETS but they find none. Keppler and Mansanet-Bataller (2010), differently from the previous papers which looked at spot prices, analyze the relationship using daily carbon futures, energy and weather data spanning the Phase I and the early Phase II periods of the EU ETS. Based on Phase I, carbon futures prices Granger cause spot prices. Furthermore, the energy spreads (that is the clean spark and dark spreads) ${ }^{7}$ and unexpected temperature changes are shown to Granger cause carbon futures prices. For Phase II, evidence is provided that the energy spreads have bidirectional causality with carbon futures. Carbon futures prices, finally, Granger cause gas prices. Nazifi and Milunovich (2010) provide further evidence that the December 2008 EUA futures contract exerts a causal effect on gas prices, and that electricity prices Granger cause spot carbon prices.

The stylized facts on the behavior of futures prices traded in Phase I with expiry in Phase II, as well as some scattered evidence of causality relationships with fundamentals during Phase I of the EU ETS, call for a deeper analysis. Therefore, our cointegration model explicitly accounts for the compliance break to investigate the existence of an equilibrum relationship since the beginning of the inter-phase futures market. This is a prerequisite to go a step further in understanding the $\mathrm{CO}_{2}$ equilibrium price as determined by the market fundamentals, an issue neglected by the recent literature on long-run relationships in carbon markets. We do believe that this is an important issue, as it also delivers information on the source of possible discrepancies between the actual price and the one implied by the cointegrating relationship, thus revealing temporary market deviations from stable patterns. This turns to be another aspect of carbon markets on which little is known. In fact, only a few models in the carbon finance litera-

\footnotetext{
${ }^{7}$ The clean dark comprises the discrepancies between the electricity price at peak hours and the price of coal, whereas the clean spark measures the differential between peak electricity price and natural gas price.
} 
ture have attempted to forecast Phase I futures prices by looking at spot prices (see for instance Daskalakis et al. 2007; Paolella et al. 2007; Seifert et al. 2008; Benz et al. 2009). However, the large variety of models considered (AR-GARCH with various innovation structures, regime-switching, Brownian augmented with jumps, etc.) attests the difficulties encountered in analyzing the complexity of the permit market due to several sources of uncertainty of the regulatory and economic environment as well as fuel prices that our approach tries to disentangle.

\section{DATA}

We consider daily data on the June 24, 2005 - December 20, 2010 period, covering thus both the Phases I and (part of) II of the EU ETS. We aim at explaining the dynamics of the carbon price, based on its main determinants such as energy prices and economic growth.

Regarding first the carbon price, which is our dependent variable, we rely on closing prices on EU allowance futures contracts denominated in euros and extracted from the European Climate Exchange (ECX) database. These contracts are traded on the ECX platform, which is the leading global marketplace for trading carbon dioxide emissions and the most liquid after the OTC market. We focus on futures contracts-rather than on spot ones-because (i) they are characterized by higher traded volumes, and (ii) they have not encountered the important structural breaks observed on the spot market (see Mansanet-Bataller and Pardo, 2008, and Bredin and Muckley, 2010). It should be noticed that various expiry dates are available on the ECX database for these contracts, and we have implemented our analysis for expiry dates until December $2012 .{ }^{8}$

Following the previous literature, we use a European equity futures index to proxy the economic and financial environment. Aside from reflecting financial and economic conditions expectations at the daily frequency, this variable allows considering the EUA as a financial asset and controls for the recent financial turmoil, at the same time providing daily data. Our retained equity variable is the Dow Jones Euro Stoxx 50, which is the Europe's leading stock index for futures contracts, extracted from Datastream. ${ }^{9}$

Energy prices are a key determinant of the carbon price, as discussed in Section 2. We consider herein two variables. The first one deals with the oil price and is represented by the ICE Brent futures index, taken from the European Climate Exchange database. Furthermore, given that the

\footnotetext{
${ }^{8}$ To save space, we only report the results based on the December 2010 expiry date. The results for the other expiry dates were very similar, showing that our findings are robust to different trading horizons. All these results are available upon request to the authors.

${ }^{9}$ Unlike Bredin and Muckley (2010), we do not include the monthly Eurostat production index, given that daily data are artificially inferred from interpolation and this could affect the estimation.
} 
cheapest emission reducing alternative with the highest probability to be implemented is fuelswitching (that is the possibility for Combined Cycle Gas Turbine plants to switch from coal to gas, and vice-versa), we proxy this abatement opportunity by calculating the price of allowances at which the marginal costs of gas and coal-fired power plants are equal (i.e. the switching price). Following Tendances Carbone (2007), the switching price—denoted as switch —is given by:

$$
0.36 \times \text { switch }+50 \% \times P_{\text {gas }}=0.86 \times \text { switch }+36 \% \times P_{\text {coal }}
$$

where $P_{\text {gas }}$ and $P_{\text {coal }}$ respectively denote the prices of gas and coal. ${ }^{10}$ For the gas price, we consider the NBP natural gas index negotiated at the National Balancing Point, extracted from the ECX database. The coal price series is the coal API2 CIF ARA contract traded on the European Energy Exchange market, taken from Datastream. This series being initially expressed in USD/ton, it has been converted into euros/ton using the daily USD/euro exchange rate (source: European Central Bank). The left hand-side term of Equation (2) measures the total marginal cost of producing electricity with a gas-fired plant in a carbon-constrained framework, and the right hand side term is the same for a coal-fired unit. Assuming that each operator has the possibility to switch from high to low cost inputs, fuel price differentials affect the technology used to produce electricity, thus fuel demand and consequently EUA demand as well. In particular, if the EUA is below the switch, there is an economic advantage to use coal-fired power plants even in carbon-constrained frameworks.

Our choice of the regressors in the cointegrating relationship relies on the production process of the power sector. ${ }^{11}$ We thus focus on input-related variables instead of using output-related measures (as clean spark and dark spread, as in Bredin et al., 2010). We think that these latter measures are influenced by the complexity of wholesale electricity pricing in specific European market platforms, which makes it difficult to detect causal effects with carbon prices. Furthermore, we omit wheather variables as the literature so far has shown that their impact on carbon prices is indirect (therefore probably non linear), since it is captured by sudden shocks in energy demand.

\footnotetext{
${ }^{10}$ Alternatively, the switching price could be measured by the ratio between gas and coal prices, as suggested by Delarue et al. (2010). The gas/coal price ratio series being highly correlated with our variable switch (the correlation coefficient is 0.974 on the whole period), it would not sensitively affect our analysis. We thus prefer to stick to the usual indicator as suggested by the previous literature on carbon price drivers.

${ }^{11}$ According to Bunn and Fezzi (2008), changing the dispatch order, e.g. switching from coal to natural gas, allows a power producer to reduce its carbon emissions per MWh by between 40 and $60 \%$. Considering that in 2009, for instance, installations in the power and heat sector account for around $75 \%$ of verified emissions and around $65 \%$ of allocated emissions (Rickels et al., 2010), fuel switching can be considered an important abatement measure within the EU-ETS market. The revelance of the switching price on carbon prices is empirically documented by Delarue et al. (2008), Denny and O'Malley (2009), and Considine et al. (2009).
} 


\section{COINTEgRATION AND CAUSALITY RESUlTS}

We rely on the cointegration methodology to identify the existence of a potential long-term, equilibrium relationship between the carbon price and its determinants. To this end, we first test for the presence of a unit root in the variables under study. According to the usual unit root tests, ${ }^{12}$ all series are integrated of order 1 . We thus proceed to the estimation of the following relationship:

$$
\text { Carbon }_{t}=\alpha+\beta_{1} \text { Brent }_{t}+\beta_{2} \text { Stoxx }_{t}+\beta_{3} \text { switch }_{t}+\epsilon_{t}
$$

where Carbon $_{t}$ and Brent $t_{t}$ respectively denote the prices of carbon and oil, Stox $x_{t}$ is the

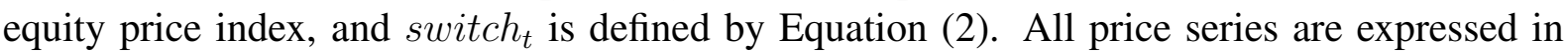
logarithmic terms. Importantly, we include a dummy variable in this relationship to account for the major break that occurred in the first phase of the EU ETS during Spring 2006. More specifically, this change happened on April 25, 2006, and is the result of the publication by France, the Netherlands, Spain and the Czech Republic of 2005 verified carbon dioxide emissions.

To assess whether Equation (3) can be considered as an equilibrium relationship, we proceed to Johansen $(1988,1991)$ 's cointegration tests. ${ }^{13}$ Table 1 reports the results of the Johansen's trace test for the whole period, as well as for the two considered subperiods corresponding respectively to Phases I and II: period 1 from June 24, 2005 to December 31, 2007, and period 2 from January 1, 2008 to December 20, 2010. Our findings indicate that the null hypothesis of no cointegration is rejected at conventional significance levels in favor of the existence of one cointegrating relationship for both the full sample and the two subperiods. While our results are consistent with those of Bredin and Muckley (2010) for period 2, they differ for the first phase of the EU ETS. This difference may be explained by the Spring 2006 break. Indeed, not accounting for this break leads us to conclude in favor of the absence of cointegration during the first phase, a finding that may be explained by the fact that it was a transitory, pilot period characterized by an important uncertainty regarding the future evolution of this new market. However, accounting for the 2006 structural change leads us to recover a long-term relationship between the carbon price and its determinants, putting forward the well-known fact that breaks can bias cointegration tests. ${ }^{14}$

\footnotetext{
${ }^{12}$ All results are available upon request to the authors.

${ }^{13}$ As a robustness check, we also applied residual-based cointegration tests (Engle and Granger, 1987, and Phillips and Ouliaris, 1990). In addition, given that our whole sample incorporates various structural changes, we implemented cointegration tests robust to such structural breaks. All these tests led to similar conclusions, and the corresponding detailed results are available upon request.

${ }^{14}$ As demonstrated by Gregory et al. (1996), the rejection frequency of cointegration tests of the null hypothesis of no cointegration is considerably reduced in the presence of structural breaks. As a consequence, the null hypothesis may be-incorrectly_not rejected due to the existence of a break.
} 
Table 1 - Results of Johansen's cointegration trace test (p-value)

\begin{tabular}{l|ccc}
\hline \hline Null hypothesis & Whole period & Period 1 & Period 2 \\
\hline None & $0 * * *$ & 0 *** & $0.0011^{* * *}$ \\
At most 1 & 0.2969 & 0.8008 & 0.1477 \\
At most 2 & 0.5119 & 0.9316 & 0.3843 \\
At most 3 & 0.5237 & 0.9532 & $0.0150^{* *}$ \\
At most 4 & 0.3462 & 0.3775 & \\
\hline
\end{tabular}

Note: $* * *$ (resp. $\overline{\text { **): rejection of the null hypothesis at the 1\% (resp. 5\%) }}$ ignificance level.

Regarding the second period, there also exists an equilibrium relationship between the carbon price and its fundamentals, since the test concludes to the rejection of the null of no cointegration in favor of the existence of at most one cointegrating relationship. Let us now investigate more in depth such dynamics in both phases of the EU ETS.

Given the results of the Johansen's test, we estimate the cointegrating relationship between the carbon price and its three determinants on the two subperiods. While the OLS estimates of the coefficients in Equation (3) are consistent, their asymptotic distribution is generally nonGaussian, biased, and dependent on nuisance parameters associated with the correlation properties of the data. To overcome these problems, various procedures exist, such as the FullyModified OLS (FM-OLS) method proposed by Phillips and Hansen (1990), or the Dynamic OLS (DOLS) method introduced by Saikkonen (1991) and Stock and Watson (1993). The FM-OLS procedure is based on a semi-parametric correction to eliminate the problems due to the correlation between the cointegrating relationship and the regressors innovations, while the DOLS is a parametric procedure that consists in augmenting the cointegrating relationship with lead and lagged differences of the regressors to control for the endogenous feedback effect. ${ }^{15}$ For the sake of completeness, we apply both procedures here.

Results in Table 2 show that both the FM-OLS and DOLS methods lead to very similar estimates. The cointegrating relationship however is quite different between the two periods. Concerning Phase II, the estimated coefficients have all the expected, positive sign. Indeed, a rise in the oil and switching prices leads to an increase in the carbon price. This is in line with the findings of previous studies. For instance, Kanen (2006) held that oil price was the major driver of natural gas price change, and in turn, the change of the natural gas price might impact the change of the electricity price and carbon price. Convery and Redmond (2007) also confirmed that energy prices were the most important drivers of carbon prices due to the ability of power generators to switch between their fuel inputs. Finally, the equity price being a proxy of the economic and financial environment, it also drives $\mathrm{CO}_{2}$ demand and thus its futures price.

\footnotetext{
${ }^{15}$ The number of lead and lagged terms considered in the DOLS procedure has been selected using the Schwarz information criterion.
} 
Table 2 - Estimation of the cointegrating relationships

\begin{tabular}{l|cccc}
\hline \hline & Brent & Stoxx & switch & Constant \\
\hline Phase I & & & & \\
$F M-O L S$ & 0.7175 & -0.7884 & $2.77 \mathrm{E}-05$ & 4.9540 \\
& $(6.3690)$ & $(-4.9611)$ & $(0.0666)$ & $(7.1009)$ \\
DOLS & 0.7117 & -0.7676 & $5.66 \mathrm{E}-05$ & 4.8852 \\
& $(6.1480)$ & $(-4.6849)$ & $(0.1310)$ & $(6.8005)$ \\
\hline Phase II & & & & \\
$F M-O L S$ & 0.5279 & 0.5177 & 0.0055 & -0.3650 \\
& $(5.7628)$ & $(3.3934)$ & $(7.4195)$ & $(-1.0221)$ \\
DOLS & 0.5338 & 0.5009 & 0.0057 & -0.3251 \\
& $(5.6359)$ & $(3.1669)$ & $(7.2915)$ & $(-0.8893)$ \\
\hline \hline
\end{tabular}

Note: $t$-statistics of the estimated coefficients are given in parentheses, and are based on the Newey and West (1987)'s heteroskedasticity and autocorrelation consistent covariance estimator.

Regarding Phase I, two main differences can be highlighted: while the oil price also has a positive effect, (i) the sign of the stock price variable is negative, and (ii) the switch price is non significant. This latter result is similar to Alberola et al. (2008a) and is perhaps linked to the fact that there is empirical evidence that during the Phase I, carbon price has induced some emissions abatement but only in two markets: Germany, with intra-fuel substitution (brown to hard coal), and the UK, where power generation has slightly increased $\mathrm{CO}_{2}$ efficiency (Convery et al., 2008). The negative sign of the stock price coefficient suggests that, in a context of low environmental constraint despite reasonable economic growth, $\mathrm{CO}_{2}$ allowances increase the diversification of a financial portfolio and reduce the overall investment risk (Mansanet-Bataller et al., 2008). On the whole, while a cointegrating relationship exists for both phases, the nature of this relationship is different for the two subperiods.

Based on the estimation of the corresponding vector error correction models (VECM), results of Granger causality tests are displayed in Table $3 .{ }^{16}$ Important differences can be highlighted when comparing results for Phases I and II. Indeed, while the carbon price is not impacted on the short run by the considered fundamentals during Phase I, our findings illustrate that it is influenced in Phase II by the evolution of the switching price as well as stock prices. This latter

\footnotetext{
${ }^{16}$ Notice that we do not focus here on the results of the short term equation nor on the adjustment speed to the long term relationship. Two main reasons justify this choice: first, in the framework of the EU ETS market, short-term unbalances are easily absorbed by the spot or over-the-counter market; second, as surveyed in Section 2, permits sold on the spot market in Phase I could not be carried over to Phase II, thus creating very different markets underlying ECX transactions across these two periods.
} 
result gives stronger economic foundations to the results of the causality test set forth by Keppler and Mansanet-Bataller (2010) for the Phase I and early Phase II. One other interesting feature is the influence of the carbon price on both the oil and stock prices, putting forward the increasing role of the carbon market in the economy. For instance, this can signal that investing in carbon futures as financial asset on its own does no longer represent a valuable option. Compliance would thus drive the influence of carbon price on stock prices.

Table 3 - Results of Granger causality test (p-value)

\begin{tabular}{l|cccc}
\hline \hline & $\Delta$ Carbon & $\Delta$ Brent & $\Delta$ Stoxx & $\Delta$ switch \\
\hline Phase I & & & & \\
$\Delta$ Carbon & - & $0.0041^{* * *}$ & 0.7701 & 0.7262 \\
$\Delta$ Brent & 0.6261 & - & 0.3499 & 0.2970 \\
$\Delta$ Stoxx & 0.7661 & 0.1131 & - & 0.9601 \\
$\Delta$ switch & 0.5258 & 0.4642 & 0.3212 & - \\
\hline Phase II & & & & \\
$\Delta$ Carbon & - & $0.0000^{* * *}$ & $0.0871 *$ & 0.5109 \\
$\Delta$ Brent & 0.3309 & - & 0.8921 & 0.7639 \\
$\Delta$ Stoxx & $0.0470^{* *}$ & $0.0000^{* * *}$ & - & $0.0293 * *$ \\
$\Delta$ switch & $0.0062^{* * *}$ & 0.1167 & $0.0298^{* *}$ & - \\
\hline \hline
\end{tabular}

Note: The test is based on the null hypothesis that the variable $X$ in line does not cause the variable $Y$ in column. *** (resp. **, *) indicates the rejection of the null hypothesis of no causality at the $1 \%$ (resp. 5\%, 10\%) significance level.

\section{EQUILIBRIUM CARBON PRICE}

Based on the cointegrating relationship obtained for each subperiod, it is possible to derive the corresponding equilibrium carbon price. In this section, we analyze whether the carbon price observed during Phases I and II is at its equilibrium level. Looking at differences between the observed and the forecasted equilibrium price reveals potential carbon market inefficiencies ${ }^{17}$ and sheds light on the role of agents' predictions on the EU ETS.

Considering the DOLS estimates, ${ }^{18}$ the observed and equilibrium prices are reported on Figures 1 (Phase I) and 2 (Phase II), the gap between both series being displayed on Figures 3 and 4 . Given that the estimated price is the equilibrium carbon price derived from the considered fundamentals, the gap represented on Figures 3 and 4 may be interpreted as a misalignment, i.e. the difference between the observed price and its equilibrium value. Generally, the adjustment between observed and forecasted values is quite good for Phase II, while more erratic for Phase

\footnotetext{
${ }^{17}$ Exogenous shocks or the existence of rigidities induced by adjustment costs may be seen as special cases of such inefficiencies among other possible factors.

${ }^{18}$ Using the FM-OLS lead to very similar results.
} 
Figure 1 - Observed and forecasted carbon price series (in logs), Phase I

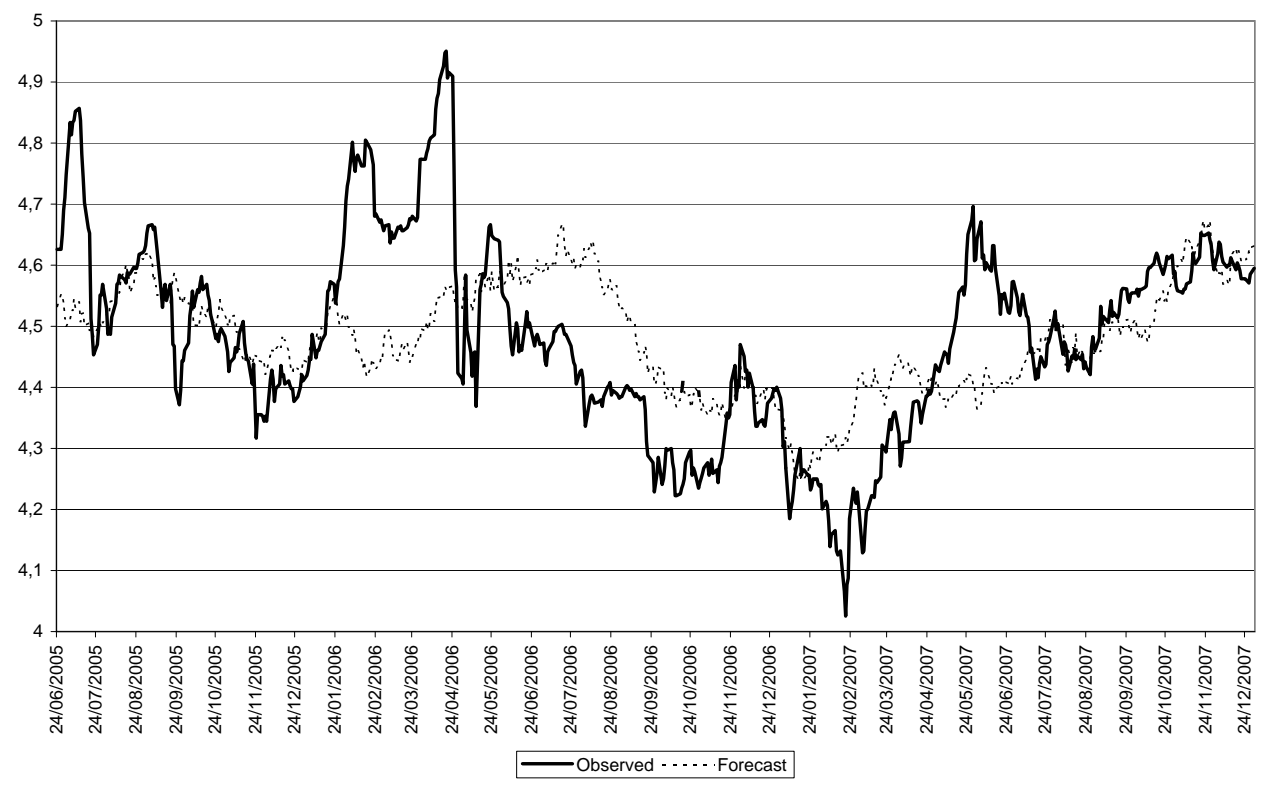

Source: authors' calculations. 
Figure 2 - Observed and forecasted carbon price series (in logs), Phase II

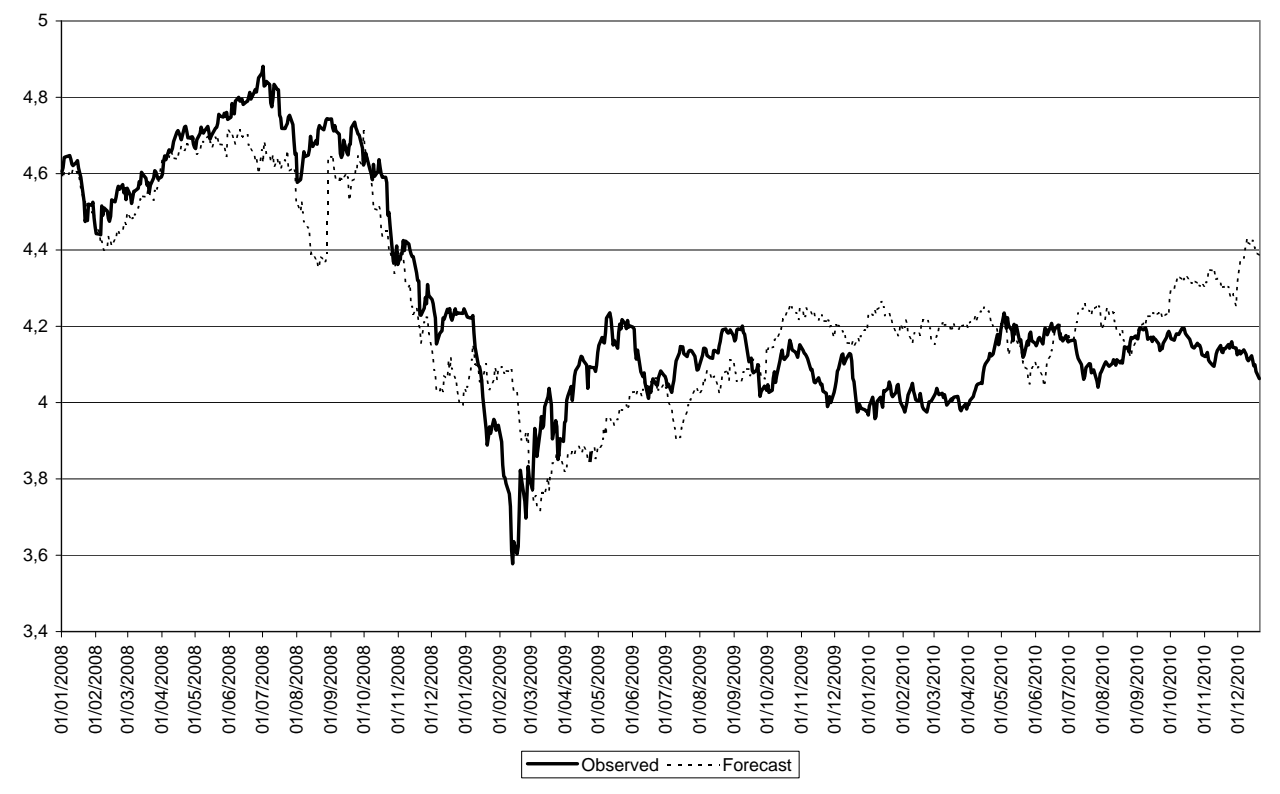

Source: authors' calculations. 
I, as long as during that period the link with switching price is rather weak (see Tables 2 and 3 ).

Regarding Phase I, the periods of over and undervaluation generally follow the observed movements of the carbon price, in that overvaluations correspond to the huge increase in the carbon price and similarly, undervaluations refer to a period of declining carbon price. The extent of misalignment is rather visible mostly during overvaluations, whose reasons span from controversial impact of energy prices as well as traders' expectations on carbon prices.

The first overvaluation episode occurs at the early operation of the EU ETS market, thus reflecting its immaturity. Here prices are $30 \%$ over their long term forecasted value. The second episode hits the market from the beginning of 2006 until April 2006. During that period, the overvaluation is about $40 \%$. An upward bias in industrial energy and emission forecasts determined an inflation in the permits price (Grubb and Ferrario, 2006). If the permits' price was set to follow market fundamentals, it would not have reached such a high level. In fact, plotting the equilibrium price against the switching price shows that energy prices would have triggered incentives to use gas instead of coal leading to a lower permits price (see Figure 5 in Appendix). After this overvaluation spell, the verification of the emissions revealing that the EU ETS installations were long by $37 \mathrm{Mt}$ in 2006 did reestablish the link between anticipations and market fundamentals. The third overvaluation episode occurs in the summer of 2007 (the difference between forecasted and observed prices remaining below 30\%). Here, the causal link between the futures permits price and the oil price played a key role. In fact, during that period, the price of a barrel of crude had a rising trend, due to supply scarcity in the world market (tensions in Nigeria, and restrictions of the gasoline supply in the United States). The upward trend in oil prices drove permits price which was not sensitive to the decrease of gas price in Europe. Furthermore, in March 2007, the European Parliament's announcement that the market would continue until 2020 boosted the price of allowances in the futures market, therefore accentuating the increase in observed prices with respect to the forecasted ones. Finally, a milder overvaluation episode occurred toward the end of Phase I. With the EUA spot price going to zero due to their non-bankability toward Phase II, the bulk of the trading shifted to the futures market, therefore creating upward pressure on ECX prices regardless the energy fundamentals. In fact, over the period July-December 2007, trades in the futures market have represented more than $85 \%$ of all transactions (Tendances Carbone, 2008).

Turning to Phase II, the comparison between observed and forecasted prices clearly unveils two distinct patterns. Until October 2009, there was an overall overvaluation (generally below 20\% but reaching almost 40\% in August 2008), except a downward spike during the 2009 winter (nearly -50\% during February). Since October 2009, a rather stable but milder undervaluation is observed, reaching -20\% during December 2010. We believe that the nature of the undervaluation episode in 2009 is different from the one that has determined the trend observed since 
the end of 2009. The misalignment between January and March 2009 can be explained by looking at the consequences on carbon demand from non-energy related sectors. As we argument below, the recent undervaluation is related to institutional factors influencing the credibility of the EU ETS market and its design.

Until the end of 2009, the market generally reacted to the fundamentals. For instance, the switch price was either above or below both the observed and the forecasted allowance price. Interestingly, the downward trend of permits price started in August 2008, in which the fall of oil prices determined a decrease in gas price, thus making more attractive this less pollutant fuel compared to coal, and in turn depressing carbon price. In the first quarter of 2009, the economic crisis further depressed the observed futures market price, leading to a marked, but transitory, undervaluation associated with a stock price index reaching its lowest level on the considered period. The severity of the price decrease has probably not been adequately reflected by the forecasted carbon price because of the impact of non-energy regulated sectors (such as steel, cement and glass) which can influence $\mathrm{CO}_{2}$ prices, as indicated by Alberola et al. (2008b). On the one hand, production cutbacks in steel, cement and glass industries resulted in a non-negligible cut in the demand - and hence in the price-for permits. On the other one, the stability of energy demand (at least at the European level) has sustained the permit price. ${ }^{19}$ The former effect has prevailed, thus causing a downward pressure on carbon prices that the equilibrium price implied by the relationship (3) captures perhaps partially. The first undervaluation period left room to a subsequent increase of the observed futures price with respect to the forecasted price, until October 2009, with energy demand finally decreasing as a consequence of the economic crisis. As from the end of 2009, the equilibrium price implied by the fundamentals is systematically below the observed one. This may be linked to several factors. First, even if the carbon price has increased compared to its February 2009 level, it remains at a very low level compared to the full period. Second, the market has probably overreacted to the uncertainty of the international climate policy. The wait-and-see attitude of the international negotiations in Copenhagen summit, in December 2009, together with concerns about the delivery of Kyoto credits, have thus triggered low carbon prices. At the beginning of 2010, other episodes amplified this lack of trust on carbon market regulation. Beyond the economic crisis, the European scheme was confronted with various types of fraud. The "carousel fraud" (failure by allowance sellers to pay back to Member States the VAT they collect) uncovered in 2009, several phishing attacks to hack into registries' accounts which were quite drastic at the end of 2010 have played a key role in lowering the exchange volume and thus the carbon price. ${ }^{20}$ The sentiment that the carbon market is fragile has therefore prevailed over the fundamentals: as from May 2010, economic

\footnotetext{
${ }^{19}$ The sectors most affected by the crisis were still well below last year production levels: metallurgy $(-29.5 \%)$, metal ore $(-26.6 \%)$, glass $(-17.8 \%)$ and cement $(-13.4 \%)$. The electricity and heat sector had a cutback of $4.6 \%$ only. Source: Tendances Carbone (2009).

${ }^{20}$ The "carousel fraud" is estimated by Europol to have cost more than 5 billion euros to EU taxpayers. Most Member States quickly implemented VAT exemptions for allowances or modified their VAT collection procedures. In the cases of phishing attempts, the alarm was sounded by the European Commission and carbon registries.
} 


\section{Figure 3 - Difference between the observed and forecasted carbon price series, Phase I}

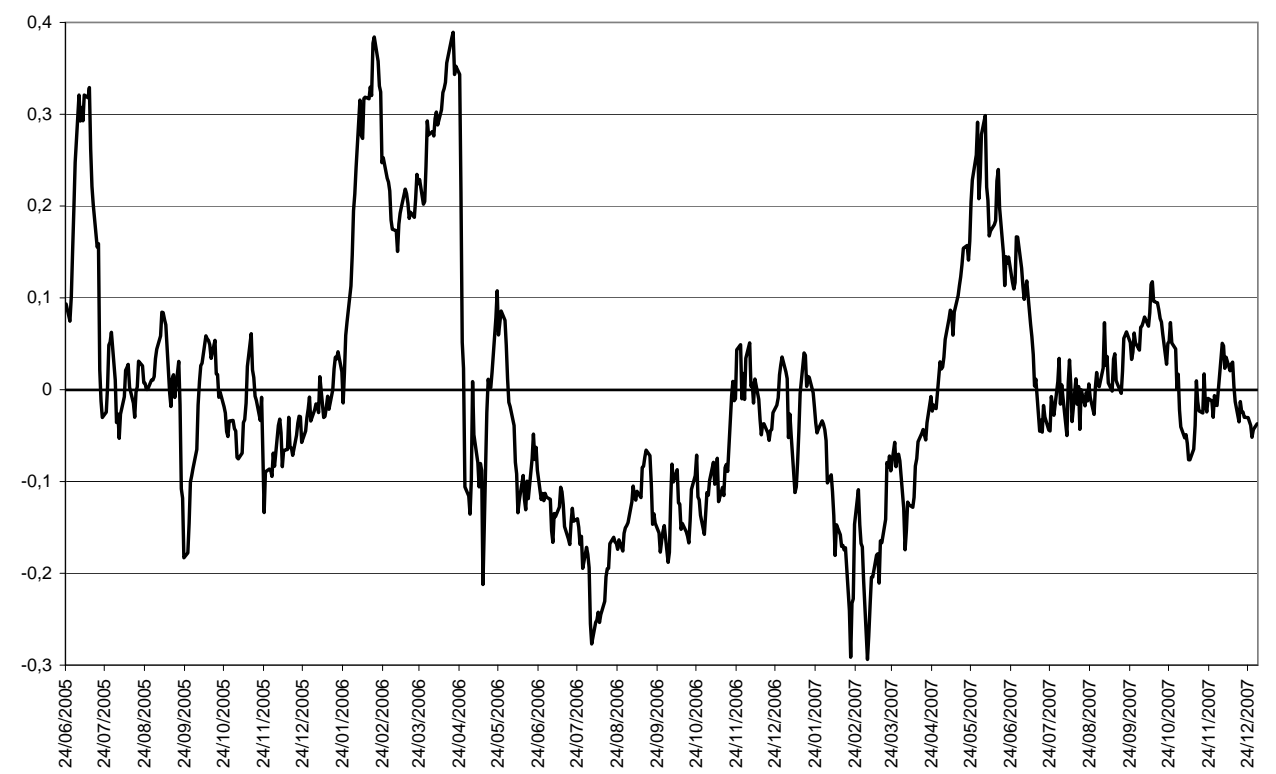

Source: authors' calculations.

signals in the energy market would have called for an increased demand for permits which did not realize. ${ }^{21}$

\section{Conclusion}

This paper investigates the determinants of the carbon price during the two phases of the European Union Emission Trading Scheme (EU ETS). More specifically, relying on daily EU allowance futures contracts, we test whether the carbon price drivers identified for Phase I still hold for Phase II and evolve toward a long-run relationship.

Using cointegration techniques, we show that while a cointegrating relationship exists between

\footnotetext{
${ }^{21}$ During the second half of 2010, the switch price has always been below the forecasted carbon price (signalling an economic advantage to use coal-fired power plants) but above the observed one (see Figure 6 in Appendix). This is the longest episode of misalignment between observed and forecasted futures price during Phase II. Other, but much shorter episodes of such kind, took place in April 2009 and February 2009.
} 
Figure 4 - Difference between the observed and forecasted carbon price series, Phase II

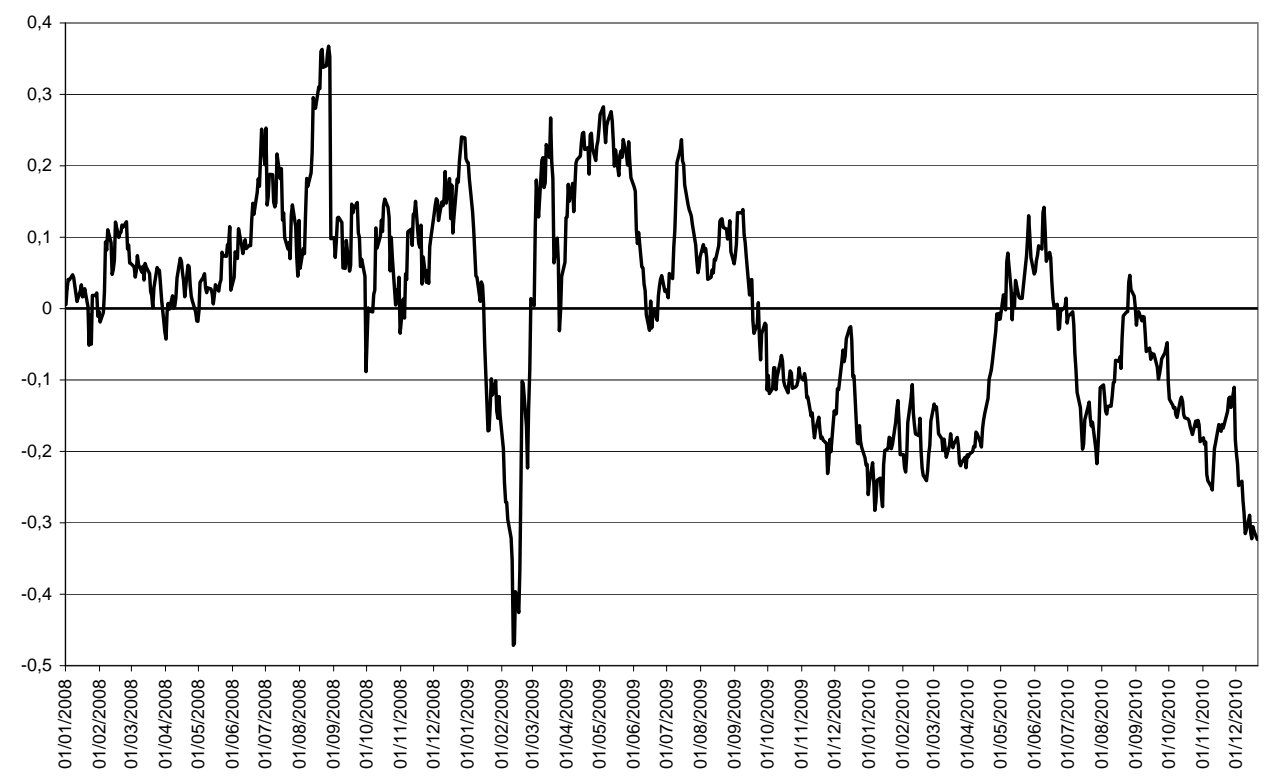

Source: authors' calculations. 
the carbon price and its fundamentals during Phase II of the EU ETS, such an equilibrium relationship can be obtained for Phase I only if the 2006 structural break that occurred on the carbon market is accounted for. On the whole, our findings highlight that equilibrium relationships exist for both phases of the EU ETS, with an increasing role of fundamentals in Phase II. In particular, while all the considered explanatory variables-namely, oil price, equity price index, and the switching price between gas and coal-are significant long-run determinants of the carbon price in the second phase of the EU ETS, the switching price does not play a key role in the first phase. Calculations of equilibrium prices show that while the observed carbon price was close to its equilibrium value and then overvalued at the beginning of Phase II, it tends to be undervalued since the end of 2009.

\section{REFERENCES}

Alberola, E., Chevallier, J., Cheze, B., 2008a, Price Drivers and Structural Breaks in European Carbon Prices 2005-2007, Energy Policy 36 (2), 787-797.

Alberola, E., Chevallier, J., Cheze, B., 2008b, The EU Emission Trading Scheme: Disentangling the Effects of Industrial Production and $\mathrm{CO}_{2}$ Emission on Carbon Prices, International Economics 116, 93-126.

Alberola, E., Chevallier, J., Cheze, B., 2009, European Carbon Price Fundamentals in 20052007: the Effects of Energy Markets, Temperatures and Sectorial Production, Journal of Policy Modeling 31(3), 446-462.

Benz, E., Trück, S., 2009, Modeling the Price Dynamics of $\mathrm{CO}_{2}$ Emission Allowances, Energy Economics 31, 4-15.

Bredin, D., Muckley, C., 2010, An emerging equilibrium in the EU emissions trading scheme, Energy Economics, doi:10.1016/j.eneco.2010.06.009.

Bunn, D., Fezzi, C., 2008, A Vector Error Correction Model of Interaction among Gas, Electricity and Carbon Prices: an application to the cases of Germany and the United Kingdom, Chapter 6 in Markets for Carbon and Power Pricing in Europe, edited by F. Gulli, Edward Elgar Publishing, London, UK,145-159.

Christiansen, A., Arvanitakis, A., Tangen, K., Hasselknippe, H., 2005, Price determinants in the EU Emissions Trading Scheme, Climate Policy 5, 15-30.

Considine, T.J., Larson, D. F., 2009, Substitution and Technological Change under Carbon Cap and Trade: Lessons from Europe, World Bank Policy Research Working Paper Series.

Convery, F., Ellerman, D., De Perthuis, C., 2008, The European Carbon Market in Action: 
Lessons from the First Trading period, Interim Report, Report 162, Cambridge, Massachusetts Institute of Technology, Center for Energy and Environmental Policy Resources.

Convery, F.J., Redmond, L., 2007, Market and Price Developments in the European Union Emissions Trading Scheme, Review of Environmental Economics and Policy 1(1), 88-111.

Crocker T. D., 1966, The Structuring of Atmospheric Pollution Control Systems. In: Wolozin H., editor. The Economics of Air Pollution. New York: Norton, 61-86.

Cronshaw, M. B., Kruse, J. B., 1993, Permit markets with banking. Working paper, Dep. of Economics, University of Colorado.

Dales J. H., 1968, Pollution, Property and Prices. Toronto: University of Toronto Press.

Daskalakis, G., Psychoyios, D., Markellos, R. N., 2007, Modeling $\mathrm{CO}_{2}$ Emission Allowance Prices and Derivatives: Evidence from the European Trading Scheme, Working Paper, Athens University of Economics and Business.

Delarue, E.D., Ellerman, A.D., D'haeseleer, W.D., 2008, Short-term CO2 Abatement in the European Power Sector, MIT CEEPR Working Paper 008.

Delarue, E.D., Ellerman, A.D., D'haeseleer, W.D., 2010, Robust MACCs? The topography of abatement by fuel switching in the European power sector, Energy 35, 1465-1475

Denny, E., O'Malley, M., 2009, The impact of carbon prices on generation-cycling costs, Energy Policy 37 (4), 1204-1212.

Ellerman, D., Convery, F., De Perthuis, C. (ed. by), 2010, Pricing Carbon: The European Union Emissions Trading Scheme, Pearson Publishers.

Engle, R.F., Granger, C.W.J., 1987, Co-integration and error correction: Representation, estimation and testing, Econometrica 55(2), 251-276.

Gregory, A.W., Nason, J.M., Watt, D.G., 1996, Testing for structural breaks in cointegrated relationships, Journal of Econometrics 71, 321-341.

Grubb, M., Ferrario, F., 2006, False confidences: forecasting errors and emission caps in CO2 trading systems, Climate Policy 6, 495-501.

Hintermann B. 2010, Allowance price drivers in the first phase of the EU ETS, Journal of Environmental Economics and Management 59, 43-56 
Johansen, S., 1988, Statistical analysis of cointegration vectors, Journal of Economic Dynamics and Control 12(2-3), 231-254.

Johansen, S., 1991, Estimation and Hypothesis Testing of Cointegration Vectors in Gaussian Vector Autoregressive Models, Econometrica 59(6), 1551-1580.

Kanen, J.L.M., 2006, Carbon Trading and Pricing, Environmental Finance Publications, London.

Keppler, J.H., Mansanet-Bataller, M., 2010, Causalities between CO2, electricity, and other energy variables during phase I and phase II of the EU ETS, Energy Policy 38(7), 3329-3341.

Mansanet-Bataller, M. and Pardo, A., 2008, $\mathrm{CO}_{2}$ Prices and Portfolio Management, Working Paper, Department of Financial Economics, University of Valencia.

Mansanet-Bataller, M., Pardo, A., Valor, E., 2007, $\mathrm{CO}_{2}$ Prices, Energy and Weather, The Energy Journal 28(3), 67-86.

Montgomery W. D.,1972, Markets in Licenses and Efficient Pollution Control Programs. Journal of Economic Theory, 5:395-418.

Milunovich, G., Joyeux, R., 2007, Testing Market Efficiency and Price Discovery in European Carbon Markets, Research Papers 0701, Macquarie University, Department of Economics.

Nazifi, F., Milunovich, G., 2010, Measuring the Impact of Carbon Allowance Trading on Energy Prices, Energy and Environment 21(5), 367-383.

Newey, W.K., West, K.D., 1987, A Simple, Positive Semi-definite, Heteroskedasticity and Autocorrelation Consistent Covariance Matrix, Econometrica 55(3), 703-708.

Paolella, M.S., Taschini, L., 2007, An Econometric Analysis of Emission-Allowance Prices, Journal of Banking and Finance 32(10), 2022-2032.

Phillips, P.C.B., Hansen, B.E., 1990, Statistical inference in instrumental variables regression with I(1) processes, Review of Economic Studies 57, 99-125.

Phillips, P.C.B., Ouliaris, S., 1990, Asymptotic Properties of Residual Based Tests for Cointegration, Econometrica 58(1), 165-193.

Rickels, W., Duscha, V., Keller, A., Peterson, S., 2007, The determinants of allowance prices in the European emission trading scheme. Can we expect an efficient allowance market 2008, Kiel Working Paper 1387, Kiel Institute for the World Economy. 
Rickels, W., Görlich D., Oberst G., 2010, Explaining European Emission Allowance Price Dynamics: Evidence from Phase II, Working Paper 1650, Kiel Institute for the World Economy.

Rubin J. D., 1996, A model of intertemporal emission trading, banking, and borrowing, Journal of Environmental Economics and Management, 31, 269-286, .

Saikkonen, P., 1991, Asymptotically efficient estimation of cointegrating regressions, Econometric Theory 58, 1-21.

Seifert, J., Uhrig-Homburg, M., Wagner, M.W., 2008, Dynamic Behavior of $\mathrm{CO}_{2}$ Spot Prices, Journal of Environmental Economics and Management 56, 180-194.

Stock, J., Watson, M., 1993, A simple estimator of cointegrating vectors in higher order integrated systems, Econometrica 61, 783-820.

Tendances Carbone, 2007, Methodological Notes.

Tendances Carbone, 2008, Monthly Bulletin n. 21.

Tendances Carbone, 2009, Monthly Bulletin n. 32.

Tietenberg, T., 1985, Emission trading: An exercise in reforming pollution policy. Working paper, Resources for the Future, Washington D.C.

\section{APPENDix}


Figure 5 - Switching price, observed and forecasted carbon price series, Phase I

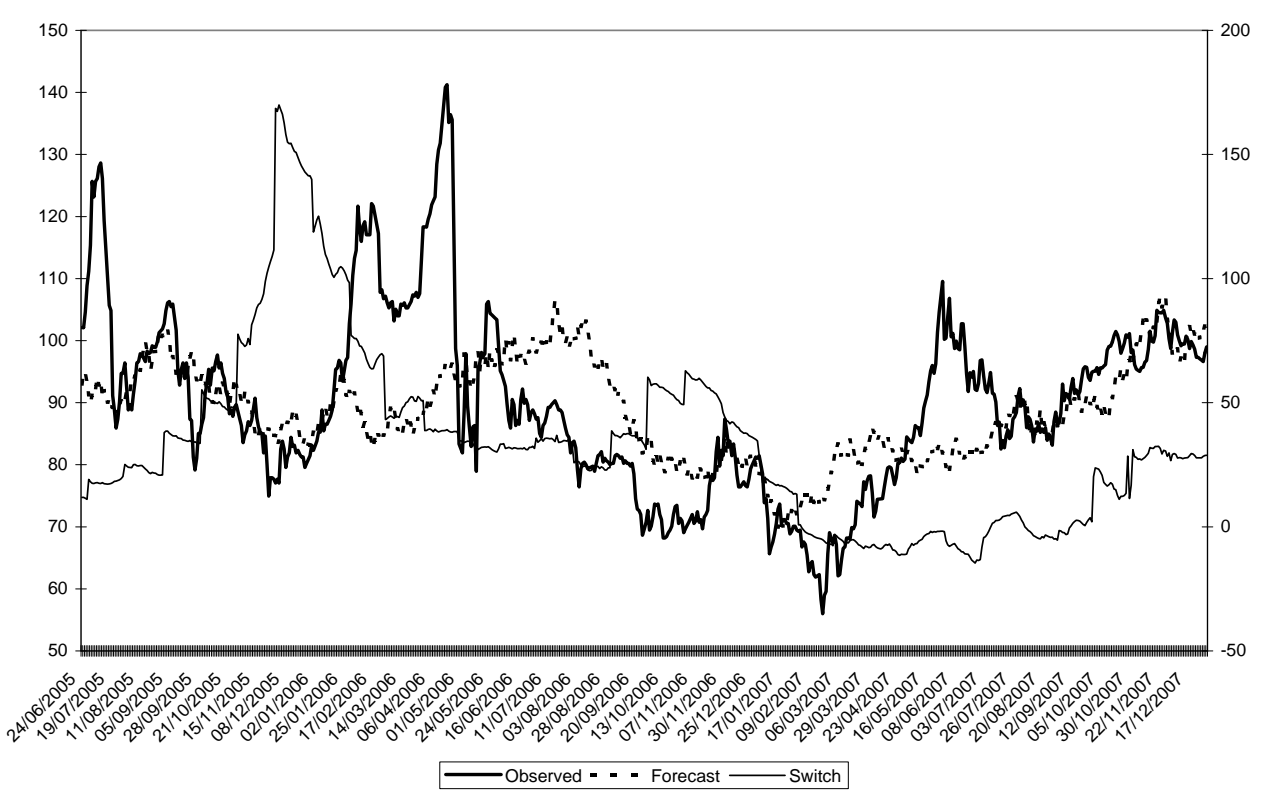


Figure 6 - Switching price, observed and forecasted carbon price series, Phase II

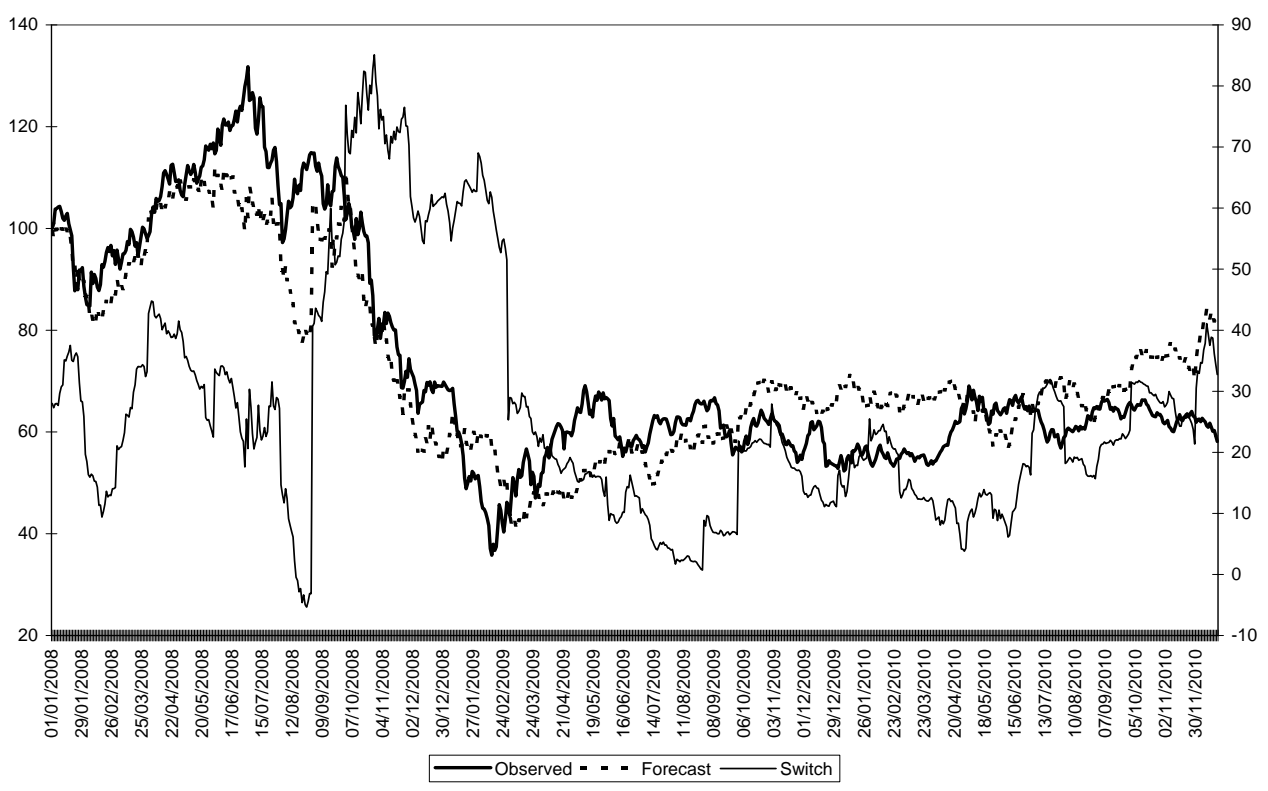




\section{LIST OF WORKING PAPERS RELEASED BY CEPII}

